DOI: $10.20472 / B M .2015 .3 .3 .003$

\title{
ECONOMIC DETERMINANTS OF REGIONAL INTEGRATION IN DEVELOPING COUNTIES
}

\section{EDUARD MARINOV}

\begin{abstract}
:
Regional integration is often viewed as a way to support development and economic growth in developing countries through the related with it benefits to trade and welfare. Economic integration theory goes through two development stages each of which addresses the political and economic context relevant for its time. The first stage is regarded as classic theory or static analysis and includes the traditional theories of economic integration that explain the possible benefits of integration. The second stage includes the new economic integration theories that are often referred to as dynamic analysis of economic arrangements. Besides these two, there is a third type of integration theories that deals with the effects, benefits and constrains of the economic integration arrangements of developing and least developed countries because in most cases, theories of economic integration and its benefits - of dynamic ones, but even more of static ones, are not fully applicable to integration agreements among developing and least developed countries. The current paper tries to come up with a conclusion on what parts of classic and new integration are applicable to the integration arrangement among developing countries and tries to summarize these theories in three main groups - general economic, market-related and trade-related factors and effects.
\end{abstract}

\section{Keywords:}

Economic Integration Theory, Developing Countries Integration

JEL Classification: F02, F15

\section{Authors:}

EDUARD MARINOV, Economic Research Institute at BAS, Bulgaria, eddie.marinov@gmail.com, Email: eddie.marinov@gmail.com

\section{Citation:}

EDUARD MARINOV (2015). Economic Determinants of Regional Integration in Developing Counties. International Journal of Business and Management, Vol. III(3), pp. 22-39., 10.20472/BM.2015.3.3.003 


\section{Introduction}

Regional economic integration is one of the main trends in the development of international economic relations in the last few decades. There are multiple examples, practically everywhere in the world, which demonstrate that it is not an isolated event, but an actual global phenomenon. The opportunities that are presented by the different forms of economic integration arrangements are growing and so are the means and ways for their utilization.

There is a clear distinction between the integration processes among developed countries where mainly the classic static and dynamic effects described by classic and new integration theory are sought, and those among developing and least developed countries - where the reasoning, the expected benefits and the clear constrains to the participation in integration arrangements are different.

\section{Economic integration - definition and types}

According to Balassa (Balassa, 1961, p. 1) economic integration can be defined as "the abolition of discrimination within an area". Kahnert defines it as "the process of removing progressively those discriminations which occur at national borders" (Kahnert et al, 1969). This is why measures that only decrease discrimination among countries are referred to as economic cooperation and not as economic integration. Allen (Allen, 1963, p. 450) claims that every researcher understands economic integration differently. That is why according to him one of the main contributions of Balassa is that he defines integration and shows its difference from cooperation - integration is a restriction of discrimination while cooperation just reduces its negative effects.

According to Lipsey economic integration theory "can be defined as that branch of tariff theory which deals with the effects of geographically discriminatory changes in trade barriers" among countries (Lipsey, 1960, p. 460).

Integration according to Machlup (1977) is the process of combining separate economies into a larger economic region. Machlup (1977) and Staley (1977, p.243) further argue that integration is concerned with the "utilization of all potential opportunities of efficient division of labour".

Different Bulgarian researchers also define integration differently. According to Shikova economic integration can be defined as a process of economic cohesion of national economies (Shikova, 2011, p.11). V. Marinov characterizes integration as a coordinated by the concerned countries process of deep coalescence of their national production processes that is objectively irreversible and leads to the gradual creation of a relatively united economic complex (Marinov, 1999, p.10). Panusheff defines economic integration as the process of integrating national economies to common mechanisms of interaction in which their independent functioning becomes an element of an upward development and source of dynamism. Savov connects economic integration with the formation of regional economic blocs ... resulting in increasing their economic interdependence (Savov, 1995, pp. 467-468).

Despite the differences in these definitions one could formulate the following simple definition of economic integration: it is the process of elimination of discrimination in trade relations between countries. A more complete definition describing economic integration with its main characteristics 
could be that it is an economic agreement between two or more countries that aims at improving welfare, which is characterized by a reduction or elimination of tariff and non-tariff barriers to trade, as well as by coordination of economic, monetary and fiscal policy, with the ultimate objective to achieve full integration, including monetary, fiscal, social and economic policies managed by supranational institutions.

\subsection{Typology of integration schemes}

Economic integration has many and various forms. A great contribution to the clarification of this issue is the book of B. Balassa "The Theory of Economic Integration" (1961), which is widely cited in all subsequent studies of economic integration - theoretical and in terms of the policy implementation. According Balassa there are four different stages of economic integration - free trade area (FTA), Customs Union (CU), common market and economic union.

Forms of economic integration are evolutive - each scheme of higher rank contains both the characteristics of the lower and new elements that expand the scope and content of the integration process. Stages can be regarded as steps of a process that has as its ultimate goal (as far as is desired by the participating countries) to achieve full integration - common monetary, social and economic policies and supranational institutions whose decisions are binding on member states.

As far as each more advanced form of integration is related to giving more national sovereignty by the participating countries, they themselves set the goals in the integration process. "The transition from one stage to another higher one means expanding the areas of economic life - the subject of integration ..." (Marinov, 1999, p.51). Although the process of integration has evolutive nature, countries that believe that this is achievable and consistent with the objectives can start the process done from one of the higher levels.

So far, there is no consensus in economic theory on the exact number and characteristics of the development forms (stages) of economic integration. In this paper I suggest a classification including eight stages of integration, based mainly on Balassa's approach of determination of their content and the differences between them.

Table 1. Stages of economic integration - main features and examples

\begin{tabular}{|c|c|c|}
\hline $\begin{array}{l}\text { Stage of } \\
\text { integration } \\
\text { process }\end{array}$ & Main features & Examples \\
\hline $\begin{array}{l}\text { Preferential } \\
\text { trade } \\
\text { agreement }\end{array}$ & $\begin{array}{l}\text { Lower trade } \\
\text { barriers between } \\
\text { member-states }\end{array}$ & $\begin{array}{l}\text { Bilateral: } \\
\text { - } \quad \text { European Union - ACP countries } \\
\text { - } \quad \text { India - MERCOSUR (2009) } \\
\text { - } \quad \text { ASEAN - PR China (2005) } \\
\text { Multilateral: } \\
\text { - } \quad \text { Asia-Pacific Trade Agreement } \\
\text { - } \quad \text { Economic Cooperation Organization (ECO) } \\
\text { - } \quad \text { Generalized System of Preferences } \\
\quad \text { Cobal System of Trade Preferences among Developing } \\
\text { - } \quad \text { Latin American Integration Association (LAIA/ALADI) } \\
\text { - } \quad \text { Pelanesian Spearhead Group (MSG) } \\
\text { Protocol on Trade Negotiations (PTN) }\end{array}$ \\
\hline
\end{tabular}




\begin{tabular}{|c|c|c|}
\hline & & $\begin{array}{ll}- & \text { South Asian Preferential Trade Arrangement (SAPTA) } \\
\text { - } & \text { South Pacific Regional Trade and Economic Cooperation } \\
& \text { Agreement (SPARTECA) }\end{array}$ \\
\hline $\begin{array}{l}\text { Free trade } \\
\text { area }\end{array}$ & Zero tariffs & $\begin{array}{ll}\text { - } & \text { ASEAN Free Trade Area (AFTA) } \\
\text { - } & \text { Asia-Pacific Trade Agreement (APTA) } \\
\text { - } & \text { Central American Integration System (SICA) } \\
\text { - } & \text { Central European Free Trade Agreement (CEFTA) } \\
\text { - } & \text { G-3 Free Trade Agreement (G-3) } \\
\text { - } \quad \text { Greater Arab Free Trade Area (GAFTA) } \\
\text { - } \quad \text { Dominican Republic-Central America Free Trade Agreement } \\
\quad \text { (DR-CAFTA) } \\
\text { - } \quad \text { Gulf Cooperation Council (GCC) } \\
\text { - } \quad \text { Pacific Alliance } \\
\text { - } \quad \text { South Asia Free Trade Agreement (SAFTA) } \\
\text { - } \quad \text { Southern African Development Community (SADC) } \\
\text { - } \quad \text { Tranthern Common Market (MERCOSUR) } \\
\end{array}$ \\
\hline $\begin{array}{l}\text { Customs } \\
\text { union }\end{array}$ & $\begin{array}{l}\text { Common customs } \\
\text { tariff }\end{array}$ & $\begin{array}{l}\text { - } \quad \text { Andean Community (CAN) } \\
\text { - } \quad \text { Southern Common Market (MERCOSUR) } \\
\text { - } \quad \text { Southern African Customs Union (SACU) } \\
\text { - } \quad \text { Customs Union of Belarus, Kazakhstan, and Russia } \\
\text { - } \quad \text { EU - Andorra, EU - San Marino, EU - Turkey } \\
\text { - } \quad \text { Israel - Palestinian Authority }\end{array}$ \\
\hline $\begin{array}{l}\text { Common } \\
\text { market }\end{array}$ & $\begin{array}{l}\text { Free movement of } \\
\text { production factors }\end{array}$ & $\begin{array}{ll} & \text { European Economic Area (EEA) } \\
\text { - } & \text { European Free Trade Association (EFTA) } \\
\text { - } & \text { South Asian Free Trade Area (SAFTA) } \\
& \text { Kazakhon Economic Space of the Customs Union of Belarus, } \\
\text { - } & \text { Switzerland - European Union } \\
\text { - } & \text { Canada - Agreement on Internal Trade } \\
\end{array}$ \\
\hline $\begin{array}{l}\text { Economic } \\
\text { union }\end{array}$ & $\begin{array}{l}\text { Harmonization } \\
\text { and coordination } \\
\text { of economic } \\
\text { policies }\end{array}$ & $\begin{array}{l}\text { - } \text { Single market of the European Union } \\
\text { - CARICOM Single Market and Economy of the Caribbean } \\
\text { - Unmunity } \\
\text { - Union State of Russia and Belarus } \\
\text { Monaco - European Union }\end{array}$ \\
\hline $\begin{array}{l}\text { Economic } \\
\text { and } \\
\text { monetary } \\
\text { union }\end{array}$ & $\begin{array}{l}\text { Common } \\
\text { monetary policy, } \\
\text { common currency }\end{array}$ & $\begin{array}{l}\text { Economic and Monetary Union of the European Union } \\
\text { - OECS Eastern Caribbean Currency Union } \\
\text { - Monaco - Eurozone }\end{array}$ \\
\hline $\begin{array}{l}\text { Full } \\
\text { economic } \\
\text { Integration }\end{array}$ & $\begin{array}{l}\text { Supranational } \\
\text { competences, } \\
\text { unification of } \\
\text { economic policies }\end{array}$ & - \\
\hline $\begin{array}{l}\text { Political } \\
\text { union }\end{array}$ & $\begin{array}{l}\text { Common policies } \\
\text { in external } \\
\text { relations, security, } \\
\text { justice, internal } \\
\text { affairs }\end{array}$ & - \\
\hline
\end{tabular}

Source: Compiled by the author. 
According to Panagariya (Panagariya, 2000, p.288) the lowest form of integration is the preferential trade agreement (PTA). It is an arrangement between two or more countries in which goods produced within the union are subject to lower trade barriers than the goods produced outside the union. A good example are the Economic partnership agreements between the European Union and the African, Carribean and Pacific countries.

A Free Trade Area (FTA) is a PTA in which member countries do not impose any trade barriers (zero tariffs) on goods produced within the union. However, each country keeps its own tariff barriers to trade with non-members. This is usually referred to as "trade integration" (Hosny, 2013, p. 134). FTA are defined in paragraph (8) of article (XXIV) of the General agreement on trade and tariffs (GATT) as follows: A free-trade area shall be understood to mean a group of two or more customs territories in which the duties and other restrictive regulations of commerce ... are eliminated on substantially all the trade between the constituent territories in products originating in such territories." A good example is the North American Free Trade Agreement (NAFTA) formed by USA, Canada, and Mexico in 1993.

A Customs Union (CU) is an FTA in which member countries apply a common external tariff on a good imported from outside countries. This common external tariff can differ across goods but not across union partners. Paragraph (8) of article (XXIV) of the GATT defines a Customs Union as follows: „A customs union shall be understood to mean the substitution of a single customs territory for two or more customs territories, so that: (i) duties and other restrictive regulations of commerce ... are eliminated with respect to substantially all the trade between the constituent territories of the union or at least with respect to substantially all the trade in products originating in such territories, and, (ii) ... substantially the same duties and other regulations of commerce are applied by each of the members of the union to the trade of territories not included in the union". The most famous example is the European Community (EC), formed in 1957 by West Germany, France, Italy, Belgium, the Netherlands, and Luxembourg.

A Common Market (CM) is a CU which further allows free movement of labour and capital among member nations. Besides this, to achieve this level of integration, it is necessary for the memberstates to remove all trade barriers (including non-tariff restrictions), as well as to have a certain level of coordination of some of the economic policies. This is usually referred to as "factor integration". At the beginning of 1993, the EU achieved the status of a CM.

Economic union (EcU) is an even more deep form of integration in which monetary and fiscal policies of individual countries are harmonized and even unified. On the basis of the common market economic policies in different areas are integrated, common approaches are formed and coordinated funding is provided. Eliminating discrimination is linked to a certain degree of coordination of national economic policies in order to remove the differences between them. This stage is often called "integration of policies".

The ultimate goal of the Economic union is the Economic and monetary union (EMU). It establishes a common exchange rate mechanism, which grows into a common currency that functions on the common market. There is a common monetary policy and coordination of macroeconomic policies of the member-states. An example of EMU is the Eurozone within the EU, which since 2001 has a common currency - the Euro. 
Balassa speaks of another stage of the integration process - the full economic integration (FEI), which "implies the unification of monetary, fiscal, social and anti-cyclical policies and requires the establishment of supranational authorities whose decisions are binding on the member-states" (Balassa, 1961, p.2). Here the formulation and implementation of economic policy is an exclusive competence of the institutions of the integration community.

Some researchers claim that there is another stage of the integration process, which however, is political. In it the ultimate political goal of integration is to achieve a political union (PU) where integration is carried out also in areas that affect national sovereignty. So far, no integration community has achieved this stage of integration, although the EU makes efforts to deepen political integration in order to become a real political union - with the introduction of the common citizenship and the attempts for implementation of common policies in foreign affairs, security, justice and internal affairs.

Table 2. Typology of integration schemes

\begin{tabular}{|c|c|c|c|c|c|c|c|c|c|}
\hline & & PTA & FTA & $\mathrm{CU}$ & CM & $\mathrm{EcU}$ & EMU & $\mathrm{FEI}$ & PU \\
\hline \multirow{5}{*}{$\begin{array}{l}\text { Freedom of } \\
\text { movement } \\
\text { within the } \\
\text { community }\end{array}$} & Goods (tariff) & & & & & & & & \\
\hline & Goods (non-tariff) & & & & & & & & \\
\hline & Services & & & & & & & & \\
\hline & Capital & & & & & & & & \\
\hline & Labour force & & & & & & & & \\
\hline \multirow{5}{*}{$\begin{array}{l}\text { Common } \\
\text { external } \\
\text { barriers }\end{array}$} & Goods (tariff) & & & & & & & & \\
\hline & Goods (non-tariff) & & & & & & & & \\
\hline & Services & & & & & & & & \\
\hline & Capital & & & & & & & & \\
\hline & Labour force & & & & & & & & \\
\hline \multirow{4}{*}{$\begin{array}{l}\text { Common } \\
\text { policies }\end{array}$} & Customs tariff & & & & & & & & \\
\hline & Monetary policy & & & & & & & & \\
\hline & Economic policies & & & & & & & & \\
\hline & Sovereign policies & & & & & & & & \\
\hline
\end{tabular}

Source: Compiled by the author.

\section{Classic and new theories on economic integration effects}

Many authors claim that economic integration theory goes through two development stages each of which addresses the political and economic issues relevant for its time. The first stage includes the traditional theories of economic integration, which explain the possible benefits of integration and are often referred to as static analysis. The second stage includes the new economic integration theories, which are developed in changed economic conditions and trade environment - they are referred to as dynamic analysis of economic arrangements.

\subsection{Static analysis}

Research of trade integration and the explanation of theoretical issues related to preferential trade agreements are based on the seminal book by Jakob Viner "The Customs Union Issue" (1951), which is often referred to as the first study of the benefits of economic integration that 
analyses them critically from an economic point of view (Catudal, 1951, p.210; Salera, 1951, p.84).

Viner's study is the first one to define specific criteria for the distinction of the pros and cons of economic integration. His so-called static analysis of economic integration distinguishes the now well-known effects of trade creation and trade diversion.

One speaks of trade creation when with signing a trade agreement between two countries trade is shifted from a higher cost producer to a lower cost producer among member-states. Trade diversion occurs when imports are shifted from a lower price producer from a third country, which is not a part of the integration agreement to a higher price producer from a member-state. This happens when a common customs tariff is applied if the integration agreement protects the higher cost supplier from a member-state.

Viner claims that trade creation increases a country's welfare while trade diversion reduces it. When speaking about the role of Customs unions on increasing economic welfare he says: "...customs union is only a partial, uncertain, and otherwise imperfect mean of doing what a world-wide non-discriminatory reduction of trade barriers can do more fully, more certainly, and equitably..." (Viner, 1950, p. 135). What Viner's theory practically means is that countries would have motivation to participate in integration if it would possibly bring more benefits than costs, or, in other words - when integration leads to more trade creation than trade diversion.

Many researches add on to Viner's static analysis by addressing different issues of integration effects. All of them come to the conclusion that no one-sided answer could be given to the question of whether customs unions increase global welfare or not. As Meade says, "Our main conclusion must be that it is impossible to pass judgment upon customs union in general. They may or may not be instruments for leading to a more economic use of resources. It all depends upon the particular circumstances of the case" (Meade, 1955, p. 107).

\subsection{Dynamic analysis}

Even back in the 60's, it becomes clear that static analysis of trade creation and trade diversion is not sufficient. Viner comes to the conclusion that an unpreferential trade policy (free trade) is a far better way to liberalise trade than a customs union, or, in other words the better allocation of resources is no longer applicable as a rationale for the creation of a customs union. Static effects analysis cannot fully assess the impact of integration on welfare, thus Bella Balassa introduces a new instrument to analyse the effects of economic integration on welfare - dynamic effects analysis - as a better means of explaining the reasons and economic rationale behind the creation of customs unions and economic integration schemes as a whole. A main thesis in international economics is that free trade on competitive markets enables production and consumption efficiency globally as well as in every single country. At first, the creation of preferential trade agreements motivated by the ideas of static effects analysis is viewed as a shift towards free trade and thus is perceived as a tool to increase real income. However, this turns out not to be true - this type of analysis does not give simple answers and principles, thus the attention should be put on the dynamic analysis of economic integration (Sheer, 1981, p.53).

Balassa (Balassa, 1962) and Cooper and Massell (Cooper and Massell, 1965) are the first researchers that introduce the concept of the dynamic effects of economic integration, which adds 
a new dimension to the research in this area. Balassa defines the main dynamic effects of integration: "large-scale economies, technological change, as well as the impact of integration on market structure and competition, productivity growth, risk and uncertainty, and investment activity" (Balassa, 1961, p.117). Schiff and Winters summarise the definition of the dynamic effects of economic integration as anything that affects the rate of medium and long term economic growth of the participating in the integration agreement member-states (Schiff and Winters, 1998, p.179).

So far a number of recent studies (Sheer 1981; El-Agra 1988; De Melo and Panagariya 1993; Fernandez 1997; Lawrence 1997; Burfisher, Robinson, and Thierfelder 2003; UNCTAD 2007, p.54) have referred to the static effects and developments of the theory of economic integration (Viner and developments) as "old regionalism", while "new regionalism" is represented by dynamic effects such as increased competition, investment flows, economies of scale, technology transfer, and improved productivity" (Hosny, 2013, p.139). Some researchers call the two theories "irst and second" regionalism, while others seek the difference in the time frame in which the effects apply to the economies: "Short-term static effects are related to the initial shift in the behaviour of economic actors,... while long-term restructuring effects are related to the improvement of the condition for the functioning of companies and their efficiency... and competition" (Panusheff, 2003, p. 37).

New theories of economic integration are developed together with the change in global economic conditions. Lawrence (Lawrence, 1997, p.18) rightly claims that the driving forces behind previous integration efforts (simple trade creation and trade diversion) are drastically different from the factors that stand behind recent integration development, such as private sector participation, foreign direct investment, an increasing role of services, etc. Together with these, among the main effects and factors that dynamic analysis regards as coming from the participation in integration agreements are, as follows: economies of scale (Corden,1972; Balassa and Stoutjesdijk; etc.), economies of scope (Panusheff, 2003), investment creation and investment diversion (Baldwin, Forslid, and Haaland,1995), increase of competition (Marinov, 1999), etc.

The only obvious setback of dynamic analysis is that, unlike the static one, there is no reliable method for quantitative assessment of dynamic effects.

Dynamic analysis of the effects of economic integration comes from the characteristics of today's free economy. Because of their deeper scope dynamic effects have a larger impact on economic processes than static ones. The dynamic effects of economic integration can be summarized as follows: increase of investment expenditure, sustainable increase of demand, consolidation of production and increase of its specialization, improvement of the organization and management of production and production technology, rationalisation of territorial distribution and utilization of resources, increase of production efficiency, creation of economic growth, etc. (Marinov, 1999).

\section{$4 \quad$ Integration determinants in developing countries}

In most cases, theories of economic integration and its benefits - of dynamic ones, but even more of static ones, are not fully applicable to integration agreements among developing and least developed countries. Meier (Meier, 1960) claims that Viner's analysis has limited or no relevance to integration among developing countries. Even Balassa (Balassa, 1965, p.16) claims that 
theoretical literature on economic integration issues discusses customs unions only in industrialised countries. Their problems and environment are not related to economic development, but more to relative changes of production and consumption features.

The traditional theory of economic integration relies on many factors in order to reach the conclusion that net static effects determine the welfare effects of integration. Based on them, some generalisations can be made about the motivation of countries to participate in integration processes. This part of the paper will try to distinguish those factors and effects of economic integration agreements that are relevant to developing countries. The economic determinants of integration agreements that influence the motivation of developing countries to participate in integration, in terms of both expected gains and feared negative consequences, are presented here in three main groups - general economic, market-related and trade-related factors and effects.

\subsection{General economic determinants}

\section{Development perspective}

Many researchers claim that when it comes to developing countries, economic integration should be regarded an instrument for their economic development, and not that much as customs or even trade policy (Abdel Jaber, 1971; Balassa and Stoutjesdijk, 1975). Integration theory is more focused on better resource allocation while development theory and policy deals more with the benefits from faster economic growth in the long term and the utilization of under- or not at all employed resources and production factors. Thus in many developing countries integration efforts are aimed at or more focused on the implementation of common projects in the field of development - poverty reduction, support for the development of healthcare and education systems, achievement and preservation of regional security.

\section{Macroeconomic policy coordination}

Shams (Shams, 2003, p.9-10) claims that even if all trade prerequisites are fulfilled when an integration agreement among developing countries is signed, the divergence of their macroeconomic policies, combined with the lack of coordination among member-states, could reduce the potential gains of integration, especially regarding the increase of interregional trade.

The issue of macroeconomic policy coordination dates back to the studies of Kahnert (Kahnert et al, 1969) and Hirschman, (Hirschman, 1971) who argue that in order for trade agreements to be durable, participating countries should try to uniform their internal monetary and foreign exchange policies (Hirschman, 1971, p. 22) and that this could be more important in promoting trade between the member countries than the customs preferences themselves. The economic areas that should be harmonised are not limited only to macroeconomic policy, but could also include industrial, social, transport, environmental policies, etc.

\section{Size of the participating countries}

Traditional theory assumes that the larger (in economic terms) the participating countries are, the more substantial the benefits of integration will be. According to Abdel Jaber (Abdel Jaber, 1971, p.262) if the size of the economy is measured by the gross national product, integration benefits for developing countries are negligibly small. Balassa on the other hand claims that integration gains depend not only on the size of the countries participating in the integration arrangement, but 
also on their rate of economic growth. Thus, as developing economies tend to grow at higher rates than already developed ones, the benefits of integration for them would be even bigger (Balassa, 1961, p.38).

Another possible measurement of the size of the integration community is the number of population. Under this criterion, developing countries will surely benefit from integration as they are usually over populated (Hosny, 2013, p.144).

\section{Integration effects for small countries}

Kreinin claims that potential gains from economic integration can be observed more clearly in small and medium sized member-states (Kreinin, 1964, p.193-194). If integration (and trade as a whole) is carried out between a small and a large country, the benefits for the small one are bigger because there is more demand for its exports. This is very substantial when the small country is a developing one and the large country is a developed one, with higher purchasing power.

A similar view is expressed by Velko Marinov, according to who in the environment of a bigger market, the comparative advantages of small national economies are manifested in their pure nature. They improve their production and market structure and increase their efficiency. "Positive effects of the participation of small countries in economic integration are achieved in medium and long term..., they assess the positive dynamic effects as far more substantial, which justifies the short term static losses" (Marinov, 1999, p. 110-111).

The argument of the positive effect of integration on small countries has its opponents. Helleiner for instance claims that the disproportion of gains in favour of the larger country is inevitable and is a result of the disparity of the economic potential of the two countries. He argues that the small country is an unequal partner who is forced to adjust to the economic and price structure in the larger member-state (Helleiner, C.K., 1996, as in Marinov, 1999, p. 112).

\section{Market-related determinants}

The welfare effects of economic integration among developing countries should not be limited only to those on production and consumption, but should also include the potential positive impact on employment, productivity, income level, specialization, competitiveness, etc.

\section{Employment and productivity effects}

It is established that in most developing countries, there exists a situation of generally low productivity plus mounting unemployment (Hosny, 2013, p. 141). Therefore when there is trade diversion that leads to labour force to be transferred from low-productive sectors and activities to ones with higher value added, welfare will increase.

The integration benefits to employment are even more obvious (Sakamoto, 1969, p. 283). On one hand, they are related to the fact that the changes in the geographical distribution of production influence labour demand, and on the other hand the bigger flows of workers influences labour force supply (Longi and Nijkamp, 2007, p. 3), thus increasing employment possibilities and rates.

\section{Production specialization}

Developing countries in general are specialized in the production of primary products. According to Abdel Jaber (Abdel Jaber, 1971, p.256-257) there is nothing wrong with that as long as the 
economic surplus gained from this type of production could be reallocated and invested efficiently in other sectors. That however is rarely what happens in reality, thus most developing countries adopt a trade policy of diversification and import substitution to accelerate economic growth. Balanced growth can be achieved by small developing countries by increasing the size of the market, benefiting from economies of scale, and expanding their inter-industry transactions, i.e. through economic integration. For these effects to be achieved however, a strong commitment is required - both in economic and political terms.

\section{Protection for industrial development}

According to Viner, in some cases economic integration can be seen as a step towards free trade, but in others it is one towards more protection (Viner, 1950, p.41-49). There are some researchers who argue that protection trade regimes could be beneficial to developing countries. Cooper and Massell for instance believe that the main goal of integration agreements among developing countries is to support their industrial development (Cooper and Massell, 1965, p.462). This could be achieved through protection because integration, according to Sakamoto (Sakamoto, 1969, p.283-284), is equivalent to import substitution, which is a tool to support industrial development. Cooper and Massell come to the conclusion that when assessing the effects of a customs union on each member-state, one must take into account not only the change in national income, but also the development and size of each country's industry sector (Cooper and Massell, 1965, p.468).

If two developing countries create a customs union and there is a trade diversion in industrial products, welfare from the point of view of consumption, will increase when the tariffs are removed, while. On the other hand, from the point of view of production, welfare will decrease (viewed as an effective use of resources) because it will be replaced with production in one of the developing member-states that is more ineffective compared to that of developed third-countries. However, if such trade diversion is combined with a common external tariff that protects domestic industry, this could lead to the development of the industrial sector in both member-states. This would be particularly useful if the two developing countries are complementary, because this way each of them will expand their industrial production to supply the market in the other one (Cooper and Massell, 1965, p.475).

According to Elkan (Elkan, 1975, p. $59-68$ ), however, it is likely for the benefits of integration in terms of industrial production in developing countries to be unevenly distributed among the member states. He calls this effect "backwash" - where much of the economic benefits of integration are concentrated in one or a small number of member states (Elkan, 1975, p. 58), while economically weaker and geographically distant countries attain less benefits compared to their partners in the community.

\section{International competitiveness}

In the past, developing countries have sought motivation for economic integration in the benefits from trade diversion and import-substituting industrialization. Later on, with the introduction of the ideas of the dynamic effects of integration, they began to find arguments for integration in the economies of scale, investment creation, technology transfer, etc. Nowadays, however, the integration initiatives of developing countries far exceed those arguments - most of them pursue policies of trade liberalization and deregulation as part of their overall stabilization programs 
agreed with international organizations. This approach has the goal to make economic integration policies (to be) compatible and complementary to other policies in order to promote international competitiveness. Therefore, according Hosni, most developing countries regard economic integration as a tool for more competitiveness in a global economy (Hosny, 2013, p. 143).

\section{Competition and complementarity}

Even Viner suggests that countries producing competing (similar) products gain more benefits from integration than those producing complementary (different) ones (Viner, 1950). This comes from the fact that the more significant the difference in the price of the same goods in the potential member states is, the greater the benefit will be (Makower and Morton, 1961, p. 35).

This should favour developing countries, because they specialize mainly in the export of products of the primary sector, thus competing in a Viner's sense. Although this is true, the fact that the major part of their exports is directed to developed countries reduces the benefits of economic integration, because it actually does not increase the volume of intraregional trade. The very category of the products of the primary sector is too large and, if split, one can see the potential benefits of integration (Abdel Jaber, 1971, s.261). Therefore Balassa argues that Viner's understanding of the criteria for competitiveness and complementarity is not at all applicable to developing countries (Balassa, 1965, p.25). Their goal actually should be to achieve a significant degree of complementarity, thus increasing the volume of intraregional trade.

More recent studies (e.g. Inotai, 1991) continue to support the thesis that in the cases of integration between developing countries complementarity and diversity of economic structures is better. In an integration agreement between similar (competing) countries, trade comes as a result of intra-sector specialization - trade expansion of this type is observed in the developed industrial countries where the size of the market and the income rate support specialization. However, this is obviously less likely for smaller and poorer markets such as those of developing countries, and therefore integration among heterogeneous (complimentary) countries is more beneficial for them.

\subsection{Trade-related determinants}

\section{Benefits of trade diversion}

Many researchers argue that trade diversion could actually be beneficial to developing countries. First of all, integration increases the size of the market and helps to reduce costs through economies of scale and space. Second, import substitution assists the region as a whole to spend more foreign currency for the import of capital goods and thereby contributes to the increase of investment and economic growth (Linder, 1966; Sakamoto, 1969). Furthermore, trade diversion enables consumers to buy imported goods at lower prices after the removal of tariffs thereby increasing their savings. The effect of all these, however, must be weighed against the loss of tariff revenues (Elkan, 1975, p. 59), which is particularly important for developing countries, since most of those countries rely on them as their main source of revenue in the budget.

Linder and Sakamoto introduce the term "effective trade diversion". According to them, if economic integration among developing countries leads to trade diversion it should not reduce welfare because the production substitution will be from an efficient developed country (outside 
the integration agreement) towards a relatively efficient developing member-state, thus creating benefits in terms of employment and income within the community as well.

\section{$\underline{\text { Initial tariff levels }}$}

Meade assumes that the higher the initial rates of tariffs between countries entering an integration agreement are, the higher the expected benefits of integration among them will be (Meade, 1955) -because the removal of the tariff will have a greater impact in terms of both welfare and intraregional trade. This is specifically important when it comes to developing countries because the national tariffs of most of them are rather high, mainly due to their desire either to increase revenue or to protect national production.

\section{International trade as share of GDP}

Lipsey assumes that the lower the share of international trade in GDP of the member states of an integration agreement is, the greater the expected benefits of a customs union on welfare will be (Lipsey, 1960, pp. 508-509). This is very important for developing countries because trade as a percentage of GDP in low-income countries has always been lower than in countries with a high level of income, although in recent years this imbalance is decreasing (Hosny, 2013, pp. 144145). However, the same does not apply to countries with medium levels of income and least developed countries - their share of trade in GDP is even more significant than that in highincome countries. It can therefore be concluded that this criterion is not applicable to developing countries, because subgroups among them may have a larger or smaller share of trade of GDP compared with high-income countries.

\section{Share of intra-regional trade}

According to Lipsey an integration agreement will bring more benefits in terms of welfare if the share of intra-regional trade is growing, while trade with the rest of the world is decreasing (Lipsey, 1960, p.508-509). Studies show that trade between developing countries is always much weaker than that between developed countries, suggesting that the benefits of integration regarding welfare will also be smaller.

However, other researchers (Balassa, 1965; Abdel Jaber, 1971) believe that this assumption should not always be taken for granted. They list several factors that restrict trade among developing countries, arguing that if these barriers are removed, trade flows between developing countries engaged in an integration process will likely increase. These factors include: first, the low level of economic development; second, inadequate transport infrastructure and facilities; third, foreign currency control and other restrictions on imports; fourth, inadequate marketing; fifth, the lack of standardization.

\section{Fostering regional trade}

It is widely recognized that the best indicator of the success of an integration agreement is the increase of the share of intra- and inter-regional trade in the total trade flows of member states. Although this is an important aspect of integration Inotai (Inotai, 1991, p.10) believes that it should not be seen as a means to its end. Equally important are the industrial development, the adequate infrastructure, the increase of the technological level, etc. Furthermore, the growth of regional trade may be the result of trade diversion from more efficient and competitive third 
countries. Therefore it can be regarded as positive only if it is combined with improving global competitiveness as a whole.

\section{Change of the trade structure with developed countries}

A major part of the imports from developed to developing countries consists of capital goods. From the dynamic analysis point of view, integration among developing countries requires substantial investments and since most of them are imported from developed countries in the form of capital goods it is likely that the volume of imports of integrating developing countries will grow. The conclusion of Mikesell is that the long-term goal of integration between developing countries should not be to reduce trade with the outside world, but rather to change in their trade structure (Mikesell, 1965, p.209).

Sakamoto (Sakamoto, 1969, p.293) believes that if the result of integration among developing countries is the trade diversion of consumer goods, this will release more foreign currency for imports of capital goods from third (developed) countries. The volume of trade with the rest of the world may not change or may even increase, but the important thing is it changes its structure.

\section{$\underline{\text { Transport infrastructure }}$}

Transport costs reduce the potential benefits of trade integration across countries. Distance itself affects the inter-sectorial trade. This is particularly important for developing countries that enter into integration agreements for two reasons: first, as countries with similar income per capita are more dependent on inter-sectorial trade. Second, transport infrastructure and facilities in developing countries are often in poor condition or even missing, or, if existing, they are designed to promote the transport of export of primary sector products the from developing to developed countries.

Therefore, as Balassa argues, transport costs between two bordering developing countries may actually be higher than those between one of them and a remote developed country (Balassa, 1965, p.31). This must be taken into account when considering the integration of developing countries, thus according to Abdel Jaber (Abdel Jaber, 1971, p. 262) in the preparation of integration agreements between developing countries one should pay special attention to the issue of existing transport facilities and infrastructure.

\subsection{Complex theories}

\section{Static and dynamic approach}

According to many researchers, one must pay more attention to dynamic rather than to static effects when assessing integration processes among developing countries (Sakamoto, 1969; Abdel Jaber, 1971, etc.). Rueda-Junquera claims that traditional integration theory, which analyses the static effects of resource allocation, implies rather small gains for developing countries and thus the motivation for participation in integration agreements should be sought in the dynamic analysis of integration and the effects that it reveals (Rueda-Junquera, 2006, p.3-4).

According to Abdel Jaber, traditional integration theory strongly relies on the neoclassical assumptions for full employment, perfect competition, constant returns of scale and perfect mobility of production factors (Abdel Jaber, 1971, p.264-265). Thus, the analysis is restricted just 
to the static effects and the dynamic ones are those that could bring a higher economic growth rate and utilization of underemployed economic potential.

\section{The training ground theory}

Some of the issues discussed above - how to increase international competitiveness, what specialization to aim at, whether to use protection to support industrial development in integration agreements between developing countries - are thoroughly discussed in the training ground theory. According to Inotai, this theory rests on the hypothesis that through the first stages of integration among developing countries their international competitiveness could be gradually improved if they depend on the regional market in the first stage of industrialization (Inotai, 1991, p.6-7). Free trade among member-states, combined with high tariffs for third countries' imports should give temporary protection to emerging industries as well as a market that is big enough to support the future industrial development. This process is referred to as "import substituting industrialization" (Rueda-Junquera, 2006, p.4) and gives enough time for the development of the industrial sectors of developing countries. The openness to global markets could be realized on a later stage when developing countries have reached a certain degree of efficiency and technological development. Therefore economic integration among developing countries could be seen as a transition stage towards an open economy and competition with the rest of the world after a short period of training, thus the theory is called "training ground" theory.

Although it looks sound from a theoretical perspective, there are some arguments against this theory. Inotai for instance (Inotai, 1991, p. 7) argues that first of all, developing regional markets in many cases are not big enough to enable industrial development in the terms of economies of scale; second, as a result of the training process there is rather small or even no improvement; third, there are great differences in demand preferences and tastes regarding the imports from third countries compared to those coming from interregional trade. Besides, there are no guarantees that developing countries would take on and fulfil the commitment to open up and liberalise their trade with the rest of the world at a certain point, thus protection measures could become permanent instead of temporary).

\section{The package approach}

Another complex way to implement integration among developing countries is the package approach. According to Balassa and Stoutjesdijk, a package approach specifically and explicitly aims at facilitating the integration process and enhancing the stability of an integration agreement by assuring that each member-state is responsible for the implementation of a single integration project within a common package of such projects (Balassa and Stoutjesdijk, 1975, p.53). These could include transport, communication, public goods, education, science, agriculture, mining, industry, etc. An important condition for the successful application of the package approach is that comprehensive information regarding the distribution of benefits and costs of each project on each member country should be available so that there are no member-states who feel there is inequality in the gains and expenses distribution of the integration process. Balassa and Stoutjesdijk argue that although this approach may seem plausible, problems such as financing, monitoring and controlling may arise. 


\section{Conclusion}

From the above said, it is obvious that the rationale behind economic integration among developing countries could not be defined and explained just by the static and dynamic effects that determine integration between developed economies. With developing countries some factors have a stronger, while, controversially, others have a weaker impact on their willingness to participate in integration agreements.

To assess the integration benefits and costs for developing countries one must take into account their specifics such as stage of economic development, structure of the economy, production characteristics, demand preferences, trade regimes and policies, etc.

Another thing that should be noted is that while in developed countries the main rationale for economic integration comes from economic groups of stakeholders, in developing countries integration processes often initially start as a political goal and effort, which in most cases leads to unsatisfactory economic results. The complexity of the political determinants of economic integration among developing countries and their interrelations with economic rationale will be subject to further research.

\section{References}

Abdel Jaber, T. (1971) A review article: The relevance of traditional integration theory to less developed countries. Journal of Common Market Studies 9 (3): pp. 254-267.

Allen, R. L. (1963). Review of The theory of economic integration, by Bela Balassa. Economic Development and Cultural Change 11 (4): pp. 449-454.

Balassa, B. (1961) The Theory of Economic Integration. Richard D. Irwin. Homewood, Illinois.

Balassa, B. (1965) Economic development and integration. Centro De Estudios Monetario Latinoamericanos. Mexico.

Balassa, B. and A. Stoutjesdijk. (1975) Economic integration among developing countries. Journal of Common Market Studies, pp. 37-55.

Baldwin, R., R. Forslid and J. Haaland. (1995) Investment creation and investment diversion: Simulation analysis of the single market programme. NBER Working Paper no. 5364. Cambridge.

Catudal, H. M. (1951) Review of The customs union issue, by Jacob Viner. The American Journal of International Law 45 (1): pp. 209-211.

Cooper, C. A., and B. F. Massell. (1965) Toward a general theory of customs union for developing countries. The Journal of Political Economy 73 (5): pp. 461-476.

Corden, W. M. (1972) Economies of scale and customs union theory. The Journal of Political Economy 80 (3): pp. 465-475.

Elkan, P. G. (1975) Measuring the impact of economic integration among developing countries. Journal of Common Market Studies 14 (1): pp. 56-68.

Hirschman, A. (1971) A bias for hope: Essays on development and Latin America. Yale University Press. New Haven and London.

Hosny, A.S. (2013) Theories of Economic Integration: A Survey of the Economic and Political Literature. International Journal of Economy, Management and Social Sciences 2 (5) May 2013, pp. 133-155 
Inotai, Andras. (1991) Regional integration among developing countries, revisited. Policy, Research, and External Affairs Working Paper no. 643. Washington, D.C.: World Bank.

Kahnert, F, P. Richards, E. Stoutjesdijk, and P. Thomopoulos. (1969) Economic integration among developing countries. Paris: Development Center of the Organization for Economic Co-operation and Development (OECD)

Kreinin, M. (1964) On the dynamic effects of a customs union. The Journal of Political Economy 72 (2): pp. 193-195.

Lawrence, Robert Z. (1997) Preferential trading arrangements: The traditional and the new. Chapter 2 in Regional Partners in Global Markets: Limits and Possibilities of the Euro-Med Agreements, edited by Ahmed Galal and Bernard Hoekman. Center for Economic Policy Research and the Egyptian Center for Economic Studies.

Linder, S. B. (1966) Customs unions and economic development. In Latin American Economic Integration, edited by Miguel S. Wionczek. New York: Praeger.

Lipsey, R. G. (1960) The theory of customs unions: A general survey. The Economic Journal 70 (279): pp. 496-513.

Longi, S and P. Nijkamp. (2007) Economic Integration and Labour Markets: Ways Forward. In: Regionalization, Growth and Economic Integration. Physica-Verlag, pp. 3-24.

Machlup, F. (1977). A history of thought on economic integration. New York: Columbia University Press.

Makower, H., and G. Morton. (1953) A contribution towards a theory of customs union. The Economic Journal 63 (249): pp. 33-49.

Marinov, V. (1999) Regional Economic Integration. PH Stopanstvo, Sofia. (in Bulgarian)

Meade, J. E. (1955) The theory of customs unions. Amsterdam: North Holland.

Meier, G. M. (1960) Effect of a customs union on economic development. Social and Economic Studies (March 1960): pp. 29-36.

Mikesell, R. F. (1965) The theory of common markets as applied to regional arrangements among developing countries. In International Trade Theory in a Developing World, edited by Harrod and Hague. New York: St. Martin's Press.

Panagariya, A. (1998). The regionalism debate: An overview. University of Maryland.

Panusheff, E. (2003) Economic integration in the European Union. PH Nekst, Sofia. (in Bulgarian)

Rueda-Junquera, F. (2006) European integration model: Lessons for the Central American common market. Jean Monnet/Robert Shuman Paper Series 6 (4) Florida: University of Miami.

Sakamoto, J. (1969) Industrial development and integration of underdeveloped countries. Journal of Common Market Studies 7 (4): pp. 283-304.

Salera, V. (1951) Review of The customs union issue, by Jacob Viner. The Journal of Political Economy 59 (1): p.84.

Savov, S. (1995). World Economics. PH Luren, Veliko Tarnovo. (in Bulgarian)

Schiff, M. and L. A. Winters. (1998) Dynamics and politics in regional integration arrangements: An introduction. The World Bank Economic Review 12 (2): pp.177-195. 
Shams, R. (2003) Regional integration in developing countries: Some lessons based on case studies. HWWA Discussion Paper no. 251. Hamburg, Germany: Hamburg Institute of International Economics.

Sheer, A. (1981) A survey of the political economy of customs unions. Law and Contemporary Problems 44 (3): pp.33-53.

Shikova, I. (2011). Policies of the European Union. PH "Sv. Kliment Ohridski", Sofia. (in Bulgarian)

Viner, J. (1950) The Customs Union Issue. New York: Carnegie Endowment for International Peace. 